\title{
Relationship between Secondary Structure and Surface Hydrophobicity of Soybean Protein Isolate Subjected to Heat Treatment
}

\author{
Zhongjiang Wang, Yang Li, Lianzhou Jiang, Baokun Qi, and Linyi Zhou \\ College of Food Science, Northeast Agricultural University, Harbin, Heilongjiang 150030, China \\ Correspondence should be addressed to Yang Li; linyi2006ze@126.com and Lianzhou Jiang; zibeizhe@126.com
}

Received 22 October 2013; Revised 6 April 2014; Accepted 14 April 2014; Published 8 May 2014

Academic Editor: Blanca Hernández-Ledesma

Copyright (C) 2014 Zhongjiang Wang et al. This is an open access article distributed under the Creative Commons Attribution License, which permits unrestricted use, distribution, and reproduction in any medium, provided the original work is properly cited.

\begin{abstract}
This study investigated relationship between secondary structure and surface hydrophobicity of soy protein isolate (SPI) subjected to a thermal treatment at $70 \sim 90^{\circ} \mathrm{C}$. Heat denaturation increased the surface hydrophobicity and surface hydrophobicity decreased as aggregate formed. Heat caused an increase in the relative amount of $\alpha$-helix structures and an overall decrease in the amount of $\beta$ sheet structures when compared with nontreated SPI. The relative amounts of secondary structures varied with time, temperature, and intensity of heat treatment applied. The $\beta$-sheet structure was most important for its significant role in denaturation of $7 \mathrm{~S}$ globulin and following formed aggregates and even in denaturation of $11 S$ globulin. The amount of $\beta$-sheet structure in SPI had an inverse correlation with the surface hydrophobicity when the temperature was kept below $90^{\circ} \mathrm{C}$. Besides, $\beta$-turn structure increased as $\beta$-7S/B-11S aggregate formated.
\end{abstract}

\section{Introduction}

Defining and measuring protein functionality start at the level of protein structure. Biological structural-functional relationships are often revealed to adjust protein applications that are usually associated with structural transitions [1]. Thermal treatment is commonly used method to improve functionality of soy proteins, such as solubility, water absorption, gelation, emulsification, or foaming [2-6]. Previously research showed that these functional properties depend on the composition, structure, degree of dissociation, denaturation, and aggregation of the 7S and 11S globulins [7-9].

Temperature increases cause proteins to unfold, exposing the sulphydryl and hydrophobic groups. For example, glycinin has secondary structure alterations and the surface hydrophobicity increases upon heating $[8,9]$. Heating SPI, consisting of both glycinin and $\beta$-conglycinin, induces the development of specific interactions among the subunits [10] and the formation of soluble complexes between the $\beta$ subunit of $\beta$-conglycinin and the basic subunit of glycinin [11]. In contrast, heating only glycinin causes aggregation of its basic subunits. Heating soy protein dispersions at temperatures above $70^{\circ} \mathrm{C}$ causes unfolding of the globular structure, leading to protein denaturation and the formation of new intra- and intermolecular bonds, such as hydrogen bonds and electrostatic and hydrophobic interactions [11].

Surface hydrophobicity is one of the most important structure-related factors influencing the functional properties of proteins. The surface hydrophobicity is significantly correlated with protein gelation, emulsion, and foaming, which are critical properties in its application as food ingredients $[2,12]$. In different protein samples, a positive relationship between the flocculation-creaming rate constant and equilibrium oil volume fraction of emulsions with surface hydrophobicity was detected [13]. Hettiarachchy et al. [14] reported that alkali-modified soy protein adhesives with high hydrophobicities enhanced water-resistance properties. Jiang et al. [15] reported water-resistance properties of soy protein isolates films presented a close relationship with surface hydrophobicity.

Wang et al. [16] pointed out that increasing surface hydrophobicity due to the unfolding of a heated protein, 
accompanied by the formation of aggregates linked by disulfide bonds, may lead to a lower surface pressure at longterm adsorption and similar dynamic interfacial rheology. Exploring the surface hydrophobicity may be an important step in adjusting the functions and properties of a protein at the molecular level.

Surface hydrophobicity is a structure-related function, dependent on the size and shape of protein molecule, amino acid composition and sequence, and any intramolecular or intermolecular cross-links [17-19]. Though previous researches on interfacial properties/function such as foaming and emulsification have given some information on surface hydrophobicity from a structural perspective [14-18], the relationship between spatial conformations and surface hydrophobicity remains to be clearly defined.

Protein denaturation is known to expose hydrophobic groups and thus cause an increase in the surface hydrophobicity. Besides, variation in surface hydrophobicity indicates changes in hydrophobic interactions that affect formation of aggregates and denaturation of proteins [20]. Thus, study on thermal treatments explained that using the surface hydrophobicity concept is needed.

The purpose of this study was to analyze SPI structural changes following heating and the effect on surface hydrophobicity to evaluate the relationship between changes in secondary structure and the surface hydrophobicity of SPI which is helpful to give a new perspective to the elucidation of soybean protein functionality.

\section{Materials and Methods}

2.1. Preparation of SPI. SPI was prepared by suspending defatted soy flakes (donated by the Key Laboratory of Soybean Biology of Education Ministry, Soybean Research Centre of Northeast Agriculture University, China) in 15-fold water and adjusted to a $\mathrm{pH}$ of 7 with $2 \mathrm{~mol} / \mathrm{L} \mathrm{NaOH}$. After stirring for $1 \mathrm{~h}$, the suspension was centrifuged at $8,000 \mathrm{~g}$ for $30 \mathrm{~min}$. The supernatant was further subjected to isoelectric precipitation by adjusting the $\mathrm{pH}$ to 4.5 with $2 \mathrm{~mol} / \mathrm{L} \mathrm{HCl}$. The protein precipitate was obtained by centrifugation $(5,000 \mathrm{~g}$, $30 \mathrm{~min}$ ), resuspended in water, and adjusted to a $\mathrm{pH}$ of 7 with $2 \mathrm{~mol} / \mathrm{L} \mathrm{NaOH}$. After removing a small amount of insoluble substances by centrifuging at $10,000 \mathrm{~g}$ for $30 \mathrm{~min}$, the protein solution was freeze dried and ground to yield SPI powder. All procedures were carried out at room temperature. The protein content of SPI was determined by the Kjeldahl method as $86.67 \pm 1.6 \% \mathrm{~W} / \mathrm{W}(N \times 6.25)$. All other chemicals used in this study were reagent grade, unless otherwise specified.

2.2. Heat Treatment of SPI. Three grams of SPI was firstly dispersed in $50 \mathrm{~mL}$ standard buffer, namely, $0.1 \mathrm{M}$ phosphate buffer ( $\mathrm{pH}$ 7.0), followed by mixing with standard buffer, to give dispersions with the desired concentrations. The protein concentration in the solutions was determined by the Lowry assay Lowry et al. [21], with BSA as the standard protein. The aqueous dispersion was then stirred in a glass tube (sealed) and heated at temperatures from 70 to $90^{\circ} \mathrm{C}$ for $15,30,45$, 60 , or $90 \mathrm{~min}$, respectively, in a temperature-controlled bath with temperature deviations of less than $1^{\circ} \mathrm{C}$. After the heat treatment, the samples were centrifuged at $10,000 \mathrm{~g}$ for $30 \mathrm{~min}$ to remove the insoluble SPI, then immediately cooled in an ice bath, and directly subjected to further experiments.

\subsection{Differential Scanning Calorimetry (DSC). DSC thermo-} grams were recorded on a 2920 modulated DSC (TA Inc., New Castle, DE, USA) with a heating rate of $5^{\circ} \mathrm{C} / \mathrm{min}$ and temperature ranges of $25-120^{\circ} \mathrm{C}$. The instrument was calibrated for temperature and enthalpy using indium. Heated SPI samples were first freeze dried, then filled in hermetic aluminum pan with $15 \mathrm{mg}$ of $10 \%$ (w/w) soy protein dispersions in distilled water, and sealed. An empty pan was used as a reference. The enthalpy of denaturation $(\Delta \mathrm{H})$ and the temperature of denaturation $\left(T_{\mathrm{D}}\right)$ were calculated using the DSC software after manually setting the start and end points of the endothermic peak.

2.4. Surface Hydrophobicity. Surface hydrophobicity was determined using 1-anilino-8-naphthalene-sulfonate (ANS) as a fluorescence probe [22]. The protein was suspended in phosphate buffer $(0.1 \mathrm{M}, \mathrm{pH})$ in a concentration of $4 \mathrm{mg} / \mathrm{mL}$ at room temperature, with occasional stirring for $30 \mathrm{~min}$. The suspension was centrifuged at $10,000 \mathrm{~g}$ for $30 \mathrm{~min}$. Serial dilutions of the supernatant were made with the same buffer at a concentration range of $0.0025-4 \mathrm{mg} / \mathrm{mL}$. Protein concentration was determined by a method described by Lowry et al. [21]. To $2 \mathrm{~mL}$ of protein solution, $40 \mu \mathrm{L}$ of ANS solution $(8 \mathrm{mmol} / \mathrm{L}$ in $0.1 \mathrm{~mol} / \mathrm{L}, \mathrm{pH} 7.0$, phosphate buffer) was added. Fluorescence intensity (FI) was measured at $365 \mathrm{~nm}$ (excitation) and $484 \mathrm{~nm}$ (emission) on a Cary Eclipse Fluorescence Spectrophotometer (Varian Inc., Palo Alto, CA, USA). A plot of the initial slope of FI compared to the protein concentration plot was taken as an index of surface hydrophobicity.

2.5. FT-IR Microspectroscopy. FT-IR absorption spectra from 4,000 to $400 \mathrm{~cm}^{-1}$ were acquired in the transmission mode by a Nicolet Magna IR 550 FT-IR spectrometer (Thermo Fisher Scientific Inc., Waltham, MA, USA) continuously purged with dry air and equipped with liquid nitrogen cooling MCT detector. Heated SPI samples were first freeze dried and then produced by pressing in $\mathrm{KBr}$ windows $(1.5 \mathrm{mg}$ protein to $200 \mathrm{mg} \mathrm{KBr}$ ) on a Carver press at 5-6 T pressure. Each spectrum was obtained by coadding 256 interferograms at a spectrum resolution of $2.0 \mathrm{~cm}^{-1}$. The decomposition of the amide I band was performed in the region of $1700-1600 \mathrm{~cm}^{-1}$. A second-derivative analysis ("peak fitting" procedure) of the IR-SD, which was shown previously to provide reliable quantitative information, was used to obtain quantitative analysis of the secondary structural components of SPI. The "peak fitting" procedure was applied to the linear baseline correction, the Fourier self-deconvolution and the deconvoluted (difference) spectrum to resolve and quantify its individual component bands according to a Gaussian curve fit (GCF). The procedure maintained the initial band positions in an interval of $4 \pm 1 \mathrm{~cm}^{-1}$, excluded bands with negative heights, and kept the bandwidth within the expected limits in agreement with the theoretical boundaries or predictions. 
The relative amounts of the different secondary structures of SPI were determined from the second derivative of the amide I by manually computing the areas under the bands assigned to a particular substructure. The difference of the measured spectrum and the curve fit was calculated as an internal control of the success of the curve fitting process.

2.6. Statistical Analysis. Each treatment was performed in at least triplicate. Results were subjected to a one-way analysis of variance according to the general linear model procedure with least square means effects. Multiple range tests were applied to determine which means were significantly different $(P<0.05)$ according to Fisher's least significant differences (LSD). Statistical analysis was carried out using SYSTAT software (SYSTAT, Inc., Evanston, IL, USA).

\section{Results and Discussion}

3.1. Thermal Characteristics of SPI Determined by DSC. DSC can reveal structural and conformational changes of proteins. In addition, the denaturation temperatures $\left(T_{\mathrm{D}}\right.$, peak of the denaturation curve) and $\Delta \mathrm{H}$ (enthalpy of the denaturation) can be determined from the thermograms. Denaturation temperatures indicate protein thermostability, while $\Delta \mathrm{H}$ is an indication of hydrophobic/hydrophilic interactions and protein compactness $[23,24]$. The denaturation of the two major globular proteins in SPI, $\beta$-conglycinin, and glycinin, has been associated with two distinct thermal transition peaks, ranging from 68 to $75^{\circ} \mathrm{C}$ and 85 to $93^{\circ} \mathrm{C}$, respectively. In this study, the denaturation temperature of unheated SPI, as measured by DSC, for 7S and 11S was consistent with previously published work $[24,25]$. The first peak was observed at $74.2^{\circ} \mathrm{C}$ and the second at $93.7^{\circ} \mathrm{C}$, attributable to $\beta$-conglycinin and glycinin denaturation, respectively. The enthalpy of denaturation seems to vary remarkably from laboratory to laboratory. Hua et al. [2] reported that the enthalpy of denaturation of $\beta$-conglycinin and glycinin was $1.4 \mathrm{~J} / \mathrm{g}$ and $5.3 \mathrm{~J} / \mathrm{g}$, respectively, while Tang et al. [26] reported a value of $7.2 \mathrm{~J} / \mathrm{g}$ for glycinin.

In this study, variation in protein concentration only brought a slight change in the endothermic peak and $\Delta \mathrm{H}$ at all heated temperature and detected time (partly listed in Table 1). In this study, after a thermal treatment of $70^{\circ} \mathrm{C}$, there were no remarkable changes in the endothermic peak and $\Delta \mathrm{H}$. As shown in Table 1 , after thermal treatment at $80^{\circ} \mathrm{C}$ for $15 \mathrm{~min}$, the endothermic peak of $\beta$-conglycinin disappeared, indicating complete denaturation of the $\beta$ conglycinin component. The $\Delta \mathrm{H}$ of the glycinin component declined slightly by $\sim 12 \%$ after this thermal treatment, and the $T_{\mathrm{D}}$ was increased from 93.7 to $95.3-95.6^{\circ} \mathrm{C}$. Taken together, these results suggest that although this treatment was at a temperature much lower than the $T_{\mathrm{D}}$ of glycinin $\left(93.7^{\circ} \mathrm{C}\right)$, its protein conformation was partially affected under thermal treatment at $80^{\circ} \mathrm{C}$, hydrophobic cores initially buried in the interior exposed [25], and then the partially dissociated glycinin components are refolded to form more stable aggregates with a higher $T_{\mathrm{D}}$ [26]. Thus, it can be inferred that there are two types of aggregates in preheated $\left(80^{\circ} \mathrm{C}\right.$ for $15 \mathrm{~min}$ ) SPI, mainly formed from completely denatured $\beta$-conglycinin (insoluble) and a few formed from partially denatured glycinin (soluble) [26]. In contrast, both glycinin and $\beta$-conglycinin were completely denatured after a thermal treatment at a temperature of $90^{\circ} \mathrm{C}$, which is closer to the $T_{\mathrm{D}}$ of glycinin. In this case, the aggregates seemed to be simultaneously composed of completely denatured glycinin and $\beta$-conglycinin.

3.2. Surface Hydrophobicity. Surface hydrophobicity is one of the most important surface-related properties in proteins. This property allows for the detection of changes in the distribution of hydrophobic groups at the surface, which are caused by changes in the molecular structure of SPI upon denaturation. The denaturation of SPI is known to expose the hydrophobic groups, increasing surface hydrophobicity. The other factors that may cause an increase in surface hydrophobicity include dissociation of protein subunits or expansion of peptide chains [27]. However, the formation of insoluble or soluble aggregates may cause a decrease in the surface hydrophobicity.

Petruccelli and Añón [28] reported that treatment conditions, including temperature, time, and protein concentration, influenced protein surface hydrophobicity. In our study, as shown in Figure 1, heat treatment exhibited a notable influence on surface hydrophobicity of SPI. Heat treatment at $80^{\circ} \mathrm{C}$ or $90^{\circ} \mathrm{C}$ with a protein concentration of $2 \%$ for periods shorter than $45 \mathrm{~min}$ increased surface hydrophobicity of SPI. The increased surface hydrophobicity mainly related to denaturation of $\beta$-conglycinin. In contrast, longer periods of treatment caused surface hydrophobicity to decrease. Also, surface hydrophobicity of SPI heated at $70^{\circ} \mathrm{C}$ was higher than that at $80^{\circ} \mathrm{C}$ or at $90^{\circ} \mathrm{C}$ for the same treatment time. Heating at $70^{\circ} \mathrm{C}$ generally affected the structure of glycinin and $\beta$ conglycinin and convolves partly disruption of secondary and tertiary structure of SPI, uncoiling of polypeptide chains, and exposure of sulfhydryl groups and hydrophobic sites, but no certain amount of aggregate formed, which lead to a higher surface hydrophobicity. The maximum surface hydrophobicity occurred at treatment temperature of $70^{\circ} \mathrm{C}$ for $60 \mathrm{~min}$.

Surface hydrophobicity of SPI heated at $80^{\circ} \mathrm{C}$ or $90^{\circ} \mathrm{C}$ with $5 \%$ protein concentration increased linearly up to a treatment time of $30 \mathrm{~min}$. After this period, surface hydrophobicity of SPI heated at $90^{\circ} \mathrm{C}$ reached a plateau that did not change for longer treatment periods, and this phenomenon can be explained as follows: (1) heat unfolded and disassociated subunits which compose the protein molecule cause exposure of hydrophobic domains previously buried in the interior of the subunits. Those exposure of hydrophobic sites to protein's surface increased surface hydrophobicity. (2) As some acidic subunits of $11 \mathrm{~S}$ globulin linked to its B-polypeptide counterpart only through noncovalent interactions, which could break due to heat treatment to form soluble aggregate [29]. Meanwhile basic subunit peptides coagulated via hydrophobic interactions to form insoluble aggregates. The formation of aggregates formed by acidic polypeptide and basic polypeptide of $11 \mathrm{~S}$ globulin inhibited the elevation of surface hydrophobicity. (3) Insoluble aggregates formed by basic polypeptide of 11S globulin and the $\beta$-subunits of the $7 \mathrm{~S}$ 
TABLE 1: DSC characteristics of heat-treated SPI.

\begin{tabular}{|c|c|c|c|c|c|}
\hline \multirow{2}{*}{ Soy protein samples } & \multirow{2}{*}{ Protein concentration } & \multicolumn{4}{|c|}{ DSC characteristics } \\
\hline & & $T_{\mathrm{D} 1}\left({ }^{\circ} \mathrm{C}\right)$ & $T_{\mathrm{D} 2}\left({ }^{\circ} \mathrm{C}\right)$ & $\Delta H_{1}(\mathrm{~J} / \mathrm{g})$ & $\Delta H_{2}(\mathrm{~J} / \mathrm{g})$ \\
\hline Nontreated (control) & & $74.2 \pm 0.6$ & $93.7 \pm 0.8$ & $2.4 \pm 0.1$ & $7.2 \pm 0.2$ \\
\hline \multirow{2}{*}{$\begin{array}{l}\text { Heat treatment } \\
\left(70^{\circ} \mathrm{C}, 90 \mathrm{~min}\right)\end{array}$} & $2 \%$ & $73.9 \pm 0.2$ & $92.4 \pm 0.4$ & $2.2 \pm 0.1$ & $7.1 \pm 0.2$ \\
\hline & $5 \%$ & $74.7 \pm 0.3$ & $94.2 \pm 0.2$ & $2.3 \pm 0.1$ & $7.4 \pm 0.1$ \\
\hline \multirow{2}{*}{$\begin{array}{l}\text { Heat treatment } \\
\left(80^{\circ} \mathrm{C}, 15 \mathrm{~min}\right)\end{array}$} & $2 \%$ & - & $95.6 \pm 0.5$ & - & $6.5 \pm 0.3$ \\
\hline & $5 \%$ & - & $95.3 \pm 0.1$ & - & $6.7 \pm 0.2$ \\
\hline \multirow{2}{*}{$\begin{array}{l}\text { Heat treatment } \\
\left(90^{\circ} \mathrm{C}, 45 \mathrm{~min}\right)\end{array}$} & $2 \%$ & - & - & - & - \\
\hline & $5 \%$ & - & - & - & - \\
\hline
\end{tabular}

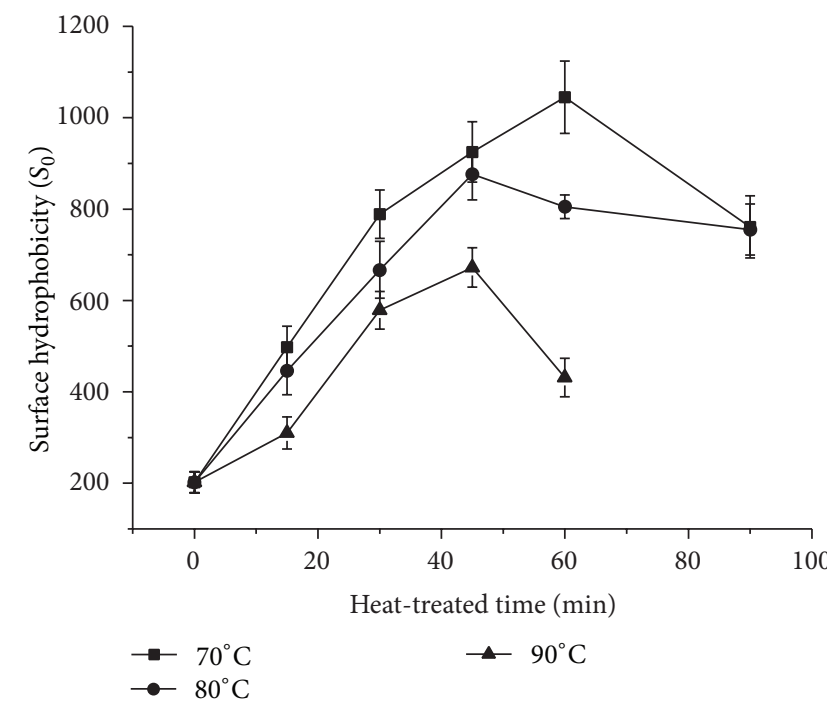

(a)

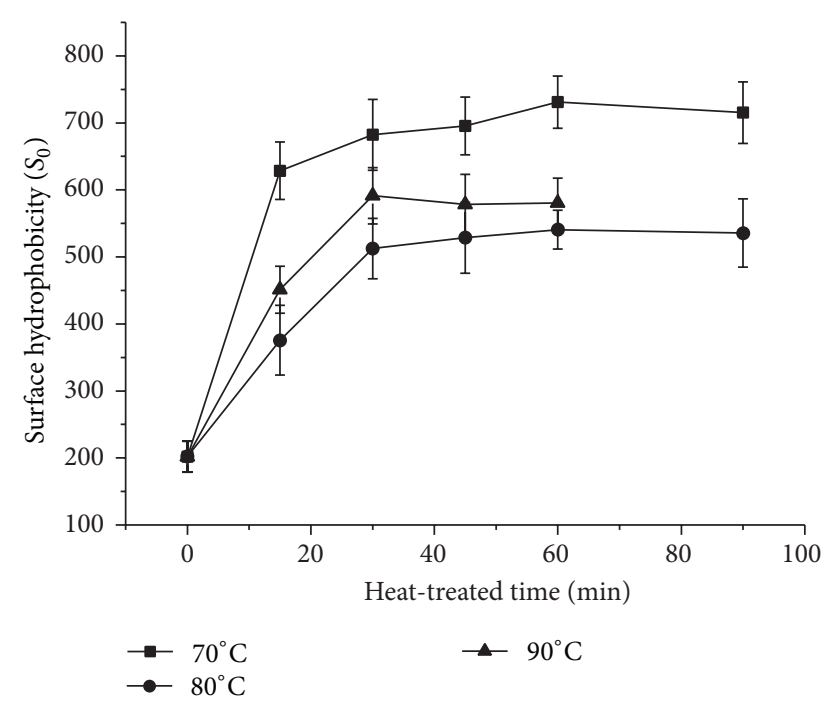

(b)

FIgURE 1: The influence of heat treatment on the surface hydrophobicity of SPI. Protein concentration at (a) 2\% (w/v) and (b) $5 \%$ (w/v).

globulin inhibit the elevation of surface hydrophobicity [30]; Petruccelli and Añón [28] pointed out that those $\beta$-7S/B-11S aggregates were initially stabilized by hydrophobic interactions and later by SS bonds. Moreover, longer heating times promoted aggregation-dissociation of AB-11S aggregates to form $\beta-7 \mathrm{~S} / \mathrm{B}-11 \mathrm{~S}$ insoluble aggregates; this may inhibit the elevation of surface hydrophobicity [28].

Additionally, hydrophobic interaction of SPI heated at $80^{\circ} \mathrm{C}$ also did not change for longer heating times; this may mainly attribute to formation of $\alpha$ and $\alpha^{\prime}-7 \mathrm{~S}$ aggregates, as heating SPI at $80^{\circ} \mathrm{C}$ totally denatured 7S globulin and partly denatured 11S globulin. Sorgentini et al. [29] reported that surface hydrophobicity of SPI increased in soluble fractions, while hydrophobic interactions did not play an important role in aggregation of proteins present in the insoluble fractions.

Heating may cause association/dissociation of subunits and disruption of the quaternary structure resulting in aggregation; thus, the decrease in surface hydrophobicity of SPI with $2 \%$ protein concentration after longer heat treatments is probably related to the formation of soluble and insoluble aggregates of subunits $[6,31]$. Similar results were previously reported, in which the basic polypeptide of $11 \mathrm{~S}$ interacted preferentially with the $\beta$ subunits of $7 \mathrm{~S}$, resulting in the precipitation of aggregates [30,31]. Also the $\alpha$ and $\alpha^{\prime}$ subunits and the acidic polypeptides interacted through disulfide bonds to form soluble aggregates. In our study, high surface hydrophobicity promotes hydrophobic interactions in the initial heat-treatment stage, while hydrophobic interactions, hydrogen bonds, and disulfide bonds were all found to play important roles in the formation of aggregates. SPI with a higher $(5 \%)$ protein concentration exhibited a relatively more stable surface hydrophobicity than that with a $2 \%$ protein concentration after longer heat-treatment periods. Li et al. [6] reported that their heat-treated samples were composed of three major fractions: aggregates, intermediate fractions, and nonaggregated molecules. The relative proportion of the aggregate fraction increased as protein concentration increased. In this study, a higher relative proportion of the aggregate fraction and the balance of the three major fractions at a $5 \%$ protein concentration might have contributed to our findings.

The surface hydrophobicity increase at $80^{\circ} \mathrm{C}$ for 15 minutes was related with denaturation of $7 \mathrm{~S}$ globulin. Interestingly, denaturation of $11 \mathrm{~S}$ globulin at $90^{\circ} \mathrm{C}$ for $45 \mathrm{~min}$ caused an increase in surface hydrophobicity of SPI with a $2 \%$ protein 
concentration, but a change was not observed with a $5 \%$ protein concentration. In addition, the sharp increase in surface hydrophobicity after treatment of $90^{\circ} \mathrm{C}$ for $30 \mathrm{~min}$ was related to the denaturation of $7 \mathrm{~S}$ globulin. The interaction between the basic polypeptide of the 11S globulin and the $\beta$ subunits of the $7 \mathrm{~S}$ globulin inhibits the elevation of surface hydrophobicity [28].

3.3. Assignments of the Amide I Band Components to Distinct Secondary Structure Elements. Figure 2 shows FT-IR spectra of SPI with different heat-treated times, while amide I band has been marked in Figure 2. The amide I mode originates mainly from the $\mathrm{C}=\mathrm{O}$ stretching vibration of the polypeptide backbone [32]. The major factors responsible for the conformational specificity of the amide I band are its sensitivity to hydrogen bonding and the characteristic coupling between transition dipoles, the latter leading to characteristic splitting effects. The magnitude of this splitting depends on the orientation and distance of interacting dipoles and thus provides information about the geometrical arrangements of peptide groups in a polypeptide chain [33].

The quantitative analysis of secondary structural components of proteins can be obtained by various experimental methods. Analysis of the second derivative of the IR-SD was shown previously to provide reliable quantitative information [34]. The areas of assigned amide I bands in the second derivative spectra correspond linearly to the amount of the different types of secondary structures present in the protein. In this study, prior to the second-derivative analysis, a baseline adjustment was performed to accurately measure the band areas of second derivative spectra in amide I and further study of Fourier self-deconvolution (FSD), which can substantially influence the number, position and intensity of the bands resolved by a Gaussian curve fit (GCF) [35, 36]. The GCF was adjusted to give the best least squares fit of the individual bands to each deconvoluted spectrum, followed by a second-derivative analysis [36]. In this analysis, we combined FSD, second derivative, and GCF to quantitatively analyze the second derivative of the spectra (Figure 3). Our second derivative band positions followed with previous data from the literature [37] that reported a strong band for $\alpha$-helix with a frequency around $1650-1660 \mathrm{~cm}^{-1}$. We also obtained several bands corresponding to $\beta$-sheet in the frequency region of $1618-1640 \mathrm{~cm}^{-1}$ and $1670-1690 \mathrm{~cm}^{-1}$ [38]. A series of bands corresponding to $\beta$-turn appeared in the 1660-1670 and $1690-1700 \mathrm{~cm}^{-1}$ range $[37,38]$. The random coil structure had a strong band close to $1645 \mathrm{~cm}^{-1}$ [37]. The percentages of $\alpha$-helix, $\beta$-sheet, unordered and $\beta$-turn structures in SPI are shown in Figure 4.

In this study, the predominant secondary structure of heated SPI is $\beta$-sheet, confirming data previously reported in other studies $[39,40]$. The relative content of secondary structure elements varied with the different heat treatments. Heat treatments caused an increase the $\alpha$-helix structure content and decreased the $\beta$-sheet structure content compared with untreated SPI sample. The protein secondary structural changes observed upon heating (decrease in $\beta$ sheet structure) are consistent with the literature [41].
In addition, the $\beta$-sheet content decreased, and $\alpha$ helix and $\beta$-turn structure generally increased, while the unordered structure content had minor differences when heated at $70^{\circ} \mathrm{C}$ with a $2 \%$ protein concentration for $45 \mathrm{~min}$. It suggested that heat induced a self-reassembly from $\beta$-sheet to $\alpha$-helix and $\beta$-turn structure, as $\beta$-sheet structure was always found in the interior of the folded molecule, and partly loss of $\beta$-sheet structure indicated exposure of hydrophobic sites of the protein that may cause an increase in surface hydrophobicity.

As shown in Figure 4(b), the overall content of secondary structure elements following heat treatment with $5 \%$ protein concentration was similar to that of nonheated SPI sample, indicating that SPI heated at $70^{\circ} \mathrm{C}$ with $5 \%$ protein concentration partly remains its original structure, but SPI heated at $70^{\circ} \mathrm{C}$ with $5 \%$ protein concentration did not have a continuous trend in comparison with that of $2 \%$ protein concentration.

From the results shown in DSC experiments, $7 \mathrm{~S}$ globulin denatured after heating for $15 \mathrm{~min}$ at $80^{\circ} \mathrm{C}$. The denaturation of 7S globulin increased $\alpha$-helix structure and reduced the $\beta$-sheet structure (as shown in Figures 4(c) and 4(d)). The unordered structure content of SPI treated with a $5 \%$ protein concentration increased and stayed constant with a $2 \%$ protein concentration in comparison with unheated SPI.

As shown in Figures 4(c) and 4(d), the $\alpha$-helix and $\beta$-turn structure contents increased and then decreased, while the $\beta$-sheet structure content decreased and then increased following heat treatment at $80^{\circ} \mathrm{C}$, irrespective of the concentration considered. It may be attributing to the denaturation of $\beta$-conglycinin and gradually formed aggregation. The denaturation of $7 \mathrm{~S}$ globulin for $15 \mathrm{~min}$ heat treatment at $80^{\circ} \mathrm{C}$ increased $\alpha$-helix structure but reduced $\beta$ sheet structure. The increased antiparallel $\beta$-sheet structure of soy protein heating at longer period was reported to be associated with aggregate formed by $\alpha^{\prime}$ and $\alpha$-7S subunits [28]. Lee et al. [42] reported that the involvement of $\beta$-sheets in the secondary structure of protein aggregates might be attributed to the relatively large surface areas for ordered hydrogen bonding. Moreover, the weaker water hydration strength of $\beta$-sheet, as compared to $\alpha$-helical structures, may play a role in the aggregate and network formation. This is due to the different geometry of the water-carbonyl group interactions in these conformations [43]. Furthermore, in this study, heat treatment at $80^{\circ} \mathrm{C}$ generally increased $\beta$ turn structure which can be a product of the unfolding of any higher order structures, where antiparallel $\beta$-strands can be formed as intermolecular $\beta$-sheets at the interphase of some aggregated molecules of the protein [33]. Heating SPI with a higher protein concentration at $80^{\circ} \mathrm{C}$ slightly increased the unordered structure content, while it decreased at a lower protein concentration. Some possible reasons may explain these results: higher protein concentration hindered the efficacy of the heat treatment, may form more aggregates and change the balance of original consistent of aggregate fraction, and then disturb the content of secondary structure elements.

As shown in Figures 4(e) and 4(f), heat SPI at $90^{\circ} \mathrm{C}$ with a $2 \%$ protein concentration increased percentage of $\alpha$-helix 


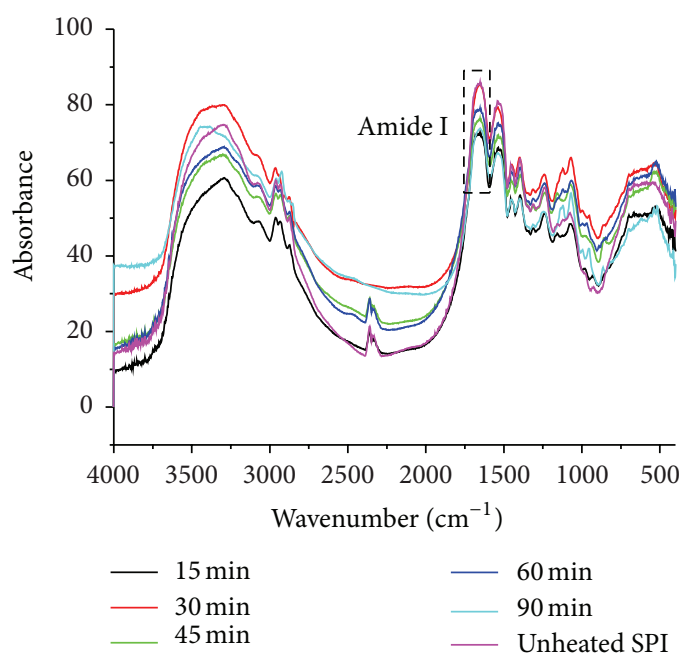

(a)
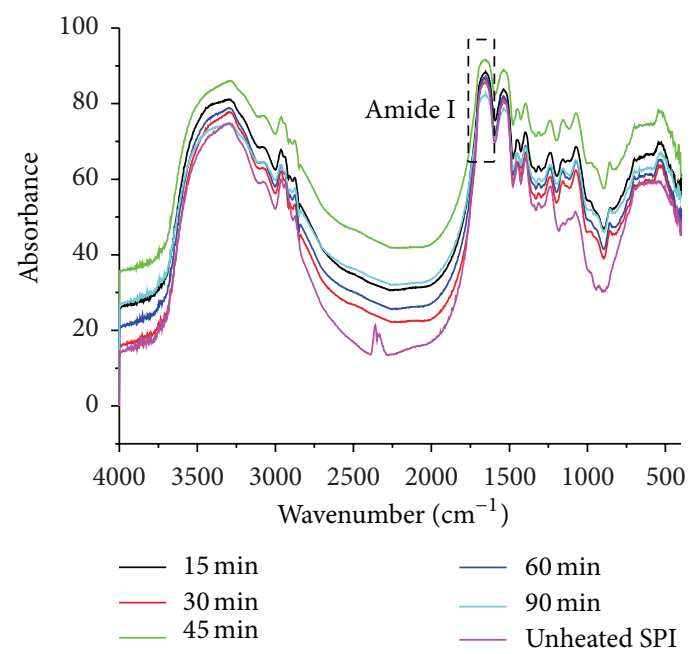

(c)

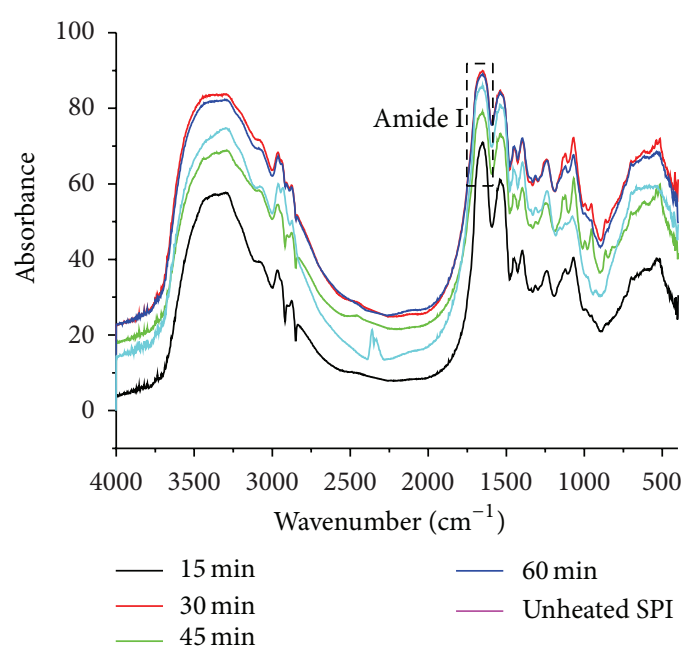

(e)

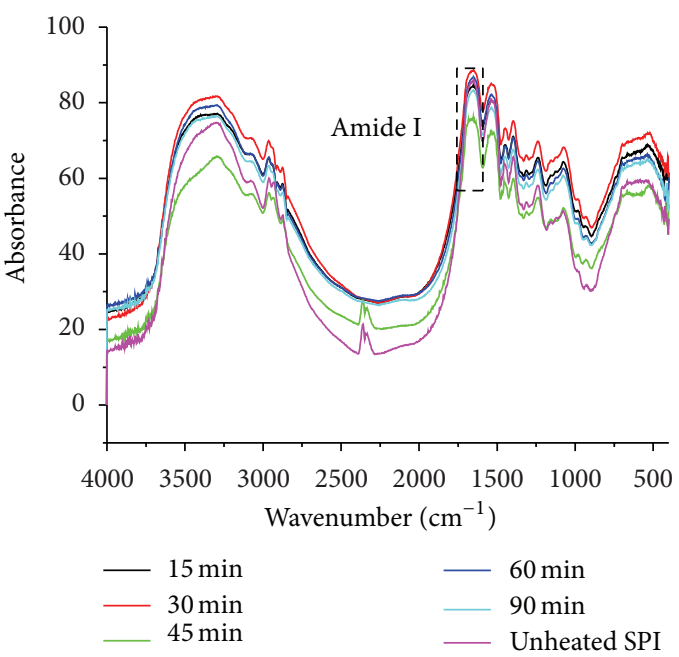

(b)

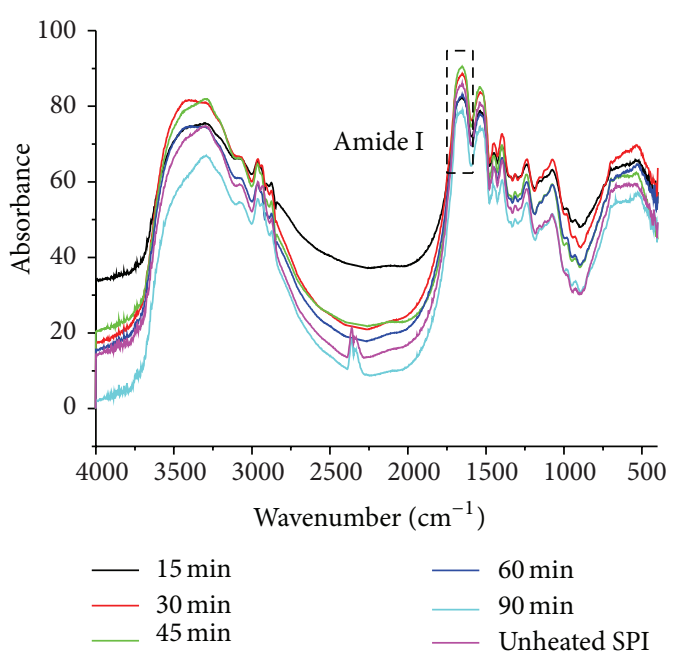

(d)

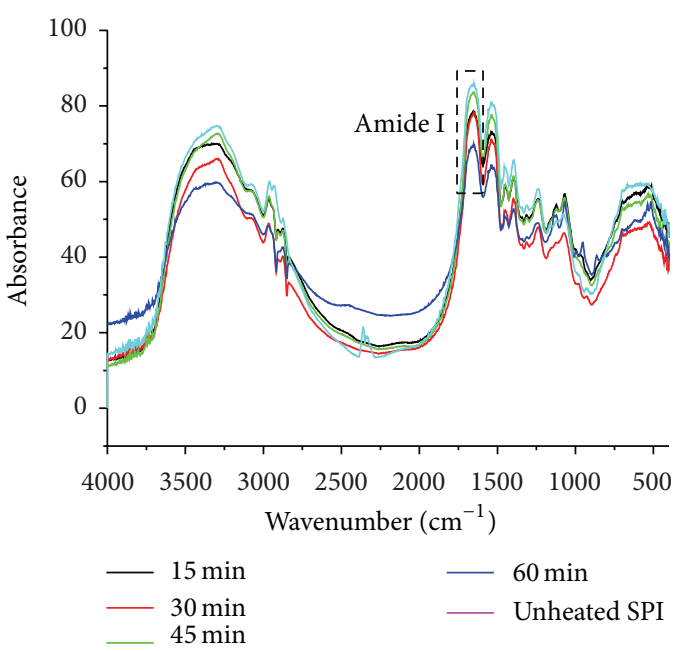

(f)

FIGURE 2: FT-IR spectra of SPI with different heat-treated times: (a) $70^{\circ} \mathrm{C}, 2 \%$; (b) $70^{\circ} \mathrm{C}, 5 \%$; (c) $80^{\circ} \mathrm{C}, 2 \%$; (d) $80^{\circ} \mathrm{C}, 5 \%$; (e) $90^{\circ} \mathrm{C}, 2 \%$; (f) $90^{\circ} \mathrm{C}$, $5 \%$. 


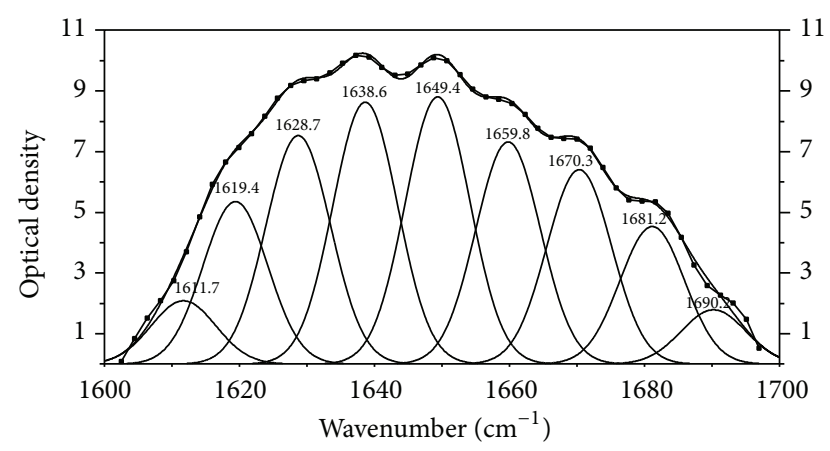

FIGURE 3: Deconvolution of the amide I spectra (continuous curve), the GCF bands thereof (point line), and the second-derivative spectra of SPI.

structure and decreased $\beta$-sheet structure. As the time of treatment increased, the percentage of $\alpha$-helix structure and $\beta$-sheet structure increased and then decreased, while the content of unordered structure showed an opposite trend. In addition, a transformation from $\alpha$-helix structure and $\beta$ sheet structure to $\beta$-turn structure was observed at $60 \mathrm{~min}$, when both 7S globulin and 11S globulin had completely denatured. It can be deduced that $\beta$-turn structure plays an important role in new formed aggregate, $\beta$-conglobulin/Bglobulin as reported by Petruccelli and Añón [28]. The larger increase in $\beta$-turn structure at $5 \%$ protein concentration may relate to the intermediate aggregate of $\mathrm{AB}$-globulin subunit enhanced by increasing protein concentration [28]. The secondary structure content of SPI heat treated at higher concentrations had a similar pattern of variation for all heattreatment times. Taken together, the denaturation of $11 \mathrm{~S}$ globulin at $45 \mathrm{~min}$ increased content of unordered structure and decreased $\beta$-structure elements, irrespective of protein concentration. Heating denatured 11S globulin with a $5 \%$ protein concentration increased $\sim 4 \%$ in percentage of $\alpha$-helix structure, while no markedly increase was observed at a $2 \%$ protein concentration.

3.4. Relationship between Surface Hydrophobicity and Secondary Structure. Kato and Nakai [22] determined surface hydrophobicity of native proteins, denatured proteins, and surfactant-bound proteins by hydrophobic partition method and finding that the surface hydrophobicity of the protein was negatively correlated with the $\alpha$-helical content. But in this study, the correlation analysis showed that there was a significant negative correlation between the content of the $\beta$ sheet structure and surface hydrophobicity $(r=-0.857, P=$ $0.029<0.05)$. However, the surface hydrophobicty exhibited a significant positive correlation with the $\beta$-turn structure of SPI heated at $70^{\circ} \mathrm{C}$ with $2 \%$ protein concentration $(r=$ $0.905, P=0.013<0.05)$. Although no significant correlation was found in a $5 \%$ protein concentration, a transformation from $\beta$-sheet to both $\alpha$-helix and $\beta$-turn occurred in SPI heat treated for $30 \mathrm{~min}$ and $60 \mathrm{~min}$, leading to an increased surface hydrophobicity, suggesting that the transformation to ordered structure elements (such as $\alpha$-helix and $\beta$-sheet structures) may be an important factor influencing the surface hydrophobicity. However, the secondary structure content following heat treatment for $60 \mathrm{~min}$ with a $5 \%$ protein concentration was similar to that of $2 \%$ protein concentration.

A similar significant negative correlation between $\beta$ sheet structure and surface hydrophobicty was found in $80^{\circ} \mathrm{C}$ heated SPI with $2 \%$ protein concentration $(r=-0.884, P=$ $0.019<0.05)$ and $5 \%$ protein concentration $(r=-0.917, P=$ $0.010 \leq 0.01$ ). Meanwhile, a significant positive correlation between surface hydrophobicity and the amount of $\alpha$-helix structure was found in heat treatments with $5 \%$ protein concentration. No significant correlation was found between surface hydrophobicity and secondary structure of SPI after heat treatments at $90^{\circ} \mathrm{C}$.

Our results indicate that the surface hydrophobicity was most likely related to the $\beta$-sheet structure of heattreated SPI, presenting an inverse correlation. One reasonable explanation for this phenomenon is that the $\beta$-sheet structure is a secondary structure connected via intermolecular or intramolecular hydrogen bonds, which facilitates maintaining the hydrophobic amino acids in the internal structure. Following heat treatment, the internal structure of SPI was partly disrupted causing the hydrophobic amino acids maintained in the internal structure to be exposed. This led to the observed changes in the surface hydrophobicity. Besides, due to relatively large surface areas for ordered hydrogen bonding, $\beta$-sheet structure may play part in the formation of aggregate, influenced by hydrophobic interaction that are essential to the stability, conformation, and function of proteins [44]. Lee et al. [42] also reported the involvement of $\beta$-sheets in the secondary structure reported to play a role in the aggregate and network formation. While surface hydrophobicity affects protein-protein interactions and then works as an indicator of hydrophobic interaction. In addition, both structure disrupted by denaturation and subunits association followed formation of aggregate may alter hydrophobicity interaction and content of $\beta$-sheet then impact on surface hydrophobicity. Thus, changes in content of $\beta$-sheet structure traced well with variation on surface hydrophobicity.

No significant correlation at $90^{\circ} \mathrm{C}$ was found due to the denaturation of 11S globulin; however, a significant correlation at $80^{\circ} \mathrm{C}$ was observed at the denaturation temperature of 7S globulin. The formation of aggregates is a reasonable explanation for this phenomenon because as time increased, heating SPI at $90^{\circ} \mathrm{C}$ dissociated their quaternary structure, denatured both $7 \mathrm{~S}$ and $11 \mathrm{~S}$ globulin, and also promoted formation of different aggregate; as discussed above, formation of $\beta-7 \mathrm{~S} / \mathrm{AB}-11 \mathrm{~S}$ aggregate followed denaturation of $11 \mathrm{~S}$ globulin mainly altered $\beta$-turn structure, while formation of $\alpha, \alpha^{\prime}-7 \mathrm{~S}$ aggregate followed denaturation of 7S globulin related with $\beta$-sheet structure.

\section{Conclusions}

Our results demonstrated that heat denaturation induced an increase in the surface hydrophobicity and surface hydrophobicity decreased with aggregate formation. The applied heat treatment increased the $\alpha$-helix structure content and decreased the $\beta$-sheet structure content compared with 


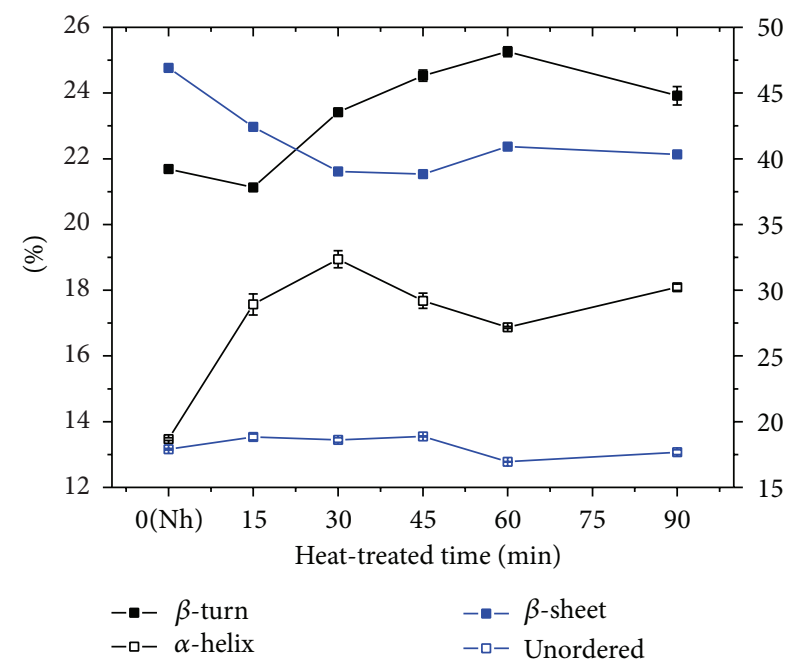

(a)

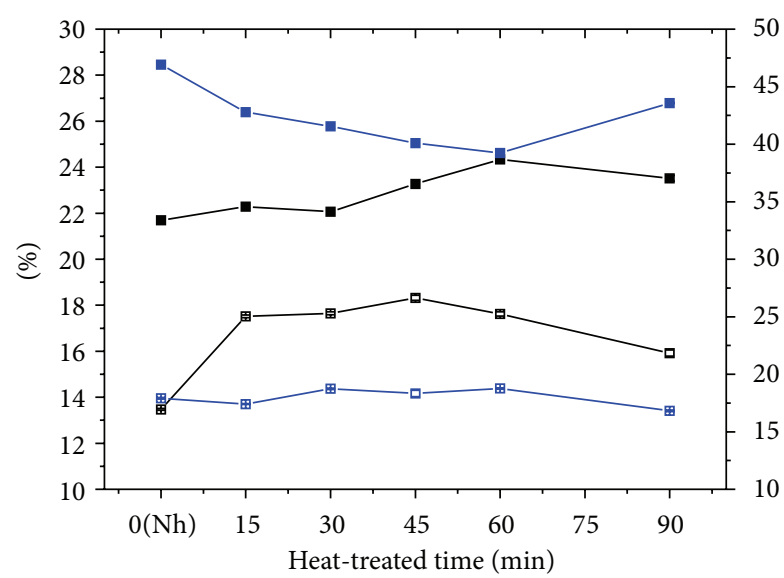

$$
\begin{array}{ll}
-\square-\beta \text {-turn } & -\square-\beta \text {-sheet } \\
-\square-\alpha \text {-helix } & -\square-\text { Unordered }
\end{array}
$$

(c)

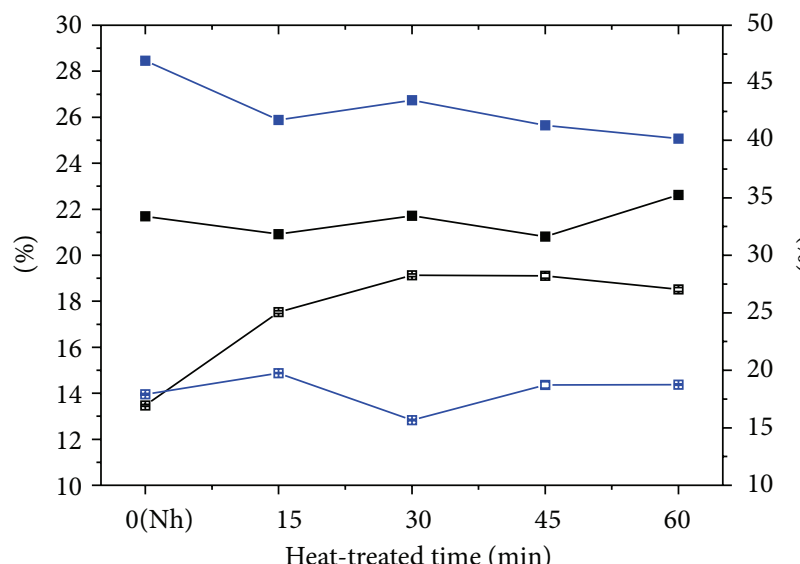

$$
\begin{array}{ll}
--\beta \text {-turn } & -\square-\beta \text {-sheet } \\
-\square-\alpha \text {-helix } & -\square-\text { Unordered }
\end{array}
$$

(e)

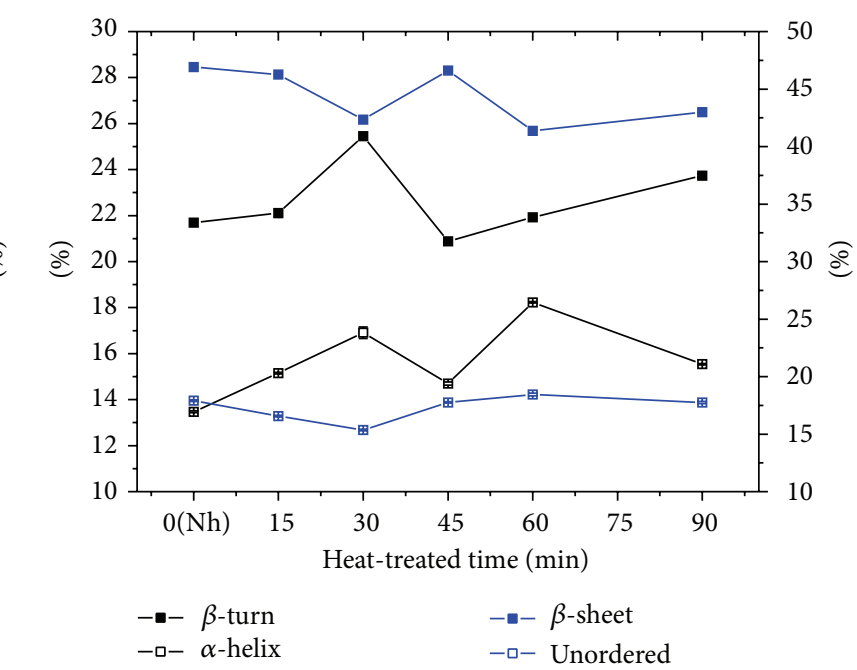

(b)

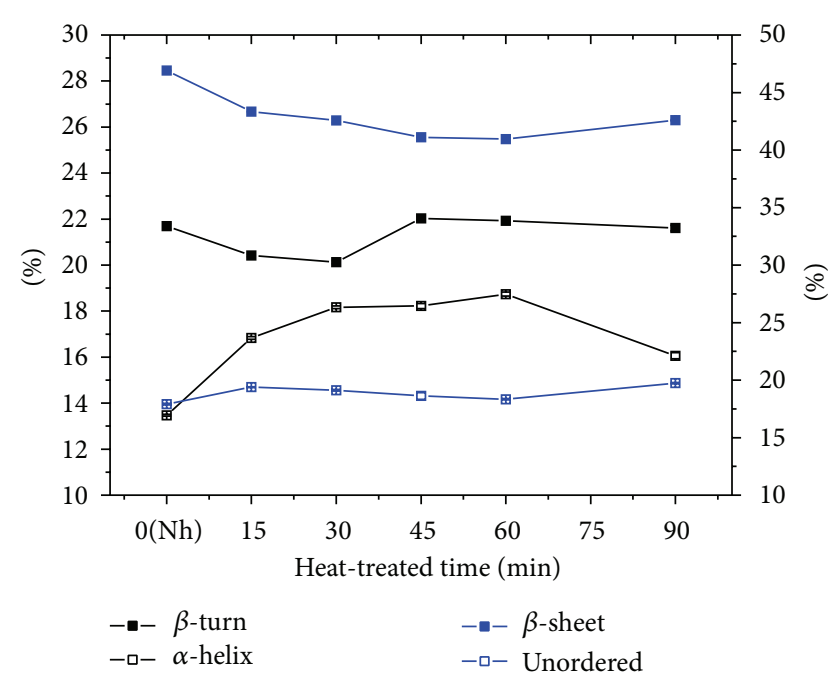

(d)

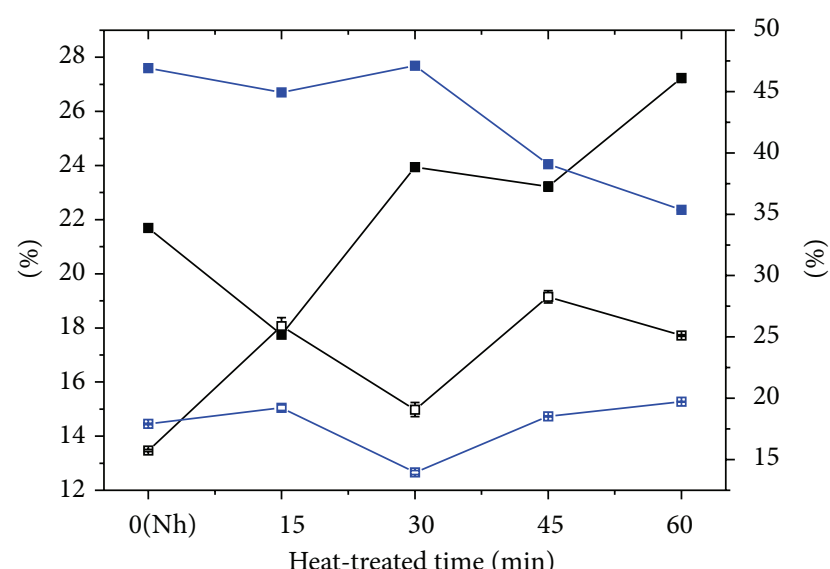

$\begin{array}{ll}--\beta \text {-turn } & --\beta \text {-sheet } \\ -\square-\alpha \text {-helix } & -\square-\text { Unordered }\end{array}$

(f)

FIGURE 4: Effects of the heat treatment on the secondary structures of SPI (nonheated SPI sample regards as 0 ). (a) SPI heated at $70^{\circ} \mathrm{C}$ with a $2 \%$ protein concentration; (b) SPI heated at $70^{\circ} \mathrm{C}$ with a $5 \%$ protein concentration; (c) SPI heated at $80^{\circ} \mathrm{C}$ with a $2 \%$ protein concentration; (d) SPI heated at $80^{\circ} \mathrm{C}$ with a $5 \%$ protein concentration; (e) SPI heated at $90^{\circ} \mathrm{C}$ with a $2 \%$ protein concentration; (f) SPI heated at $90^{\circ} \mathrm{C}$ with a $5 \%$ protein concentration. 
nonheated SPI. The secondary structure content varied with time and temperature and with the concentration of SPI. This variation was most likely due to the denaturation of $7 \mathrm{~S}$ and $11 S$ globulins and the formation of aggregates. The content of $\beta$-sheet structure showed significant inverse correlation with the surface hydrophobicity when the temperature used in the heat treatment was lower than $90^{\circ} \mathrm{C}$.

\section{Conflict of Interests}

The authors declare that there is no conflict of interests regarding the publication of this paper.

\section{Acknowledgments}

The authors would like to thank the Natural Science Foundation of China (Project No. 31071493), the Ministry of Agriculture of Modern Technology System Projects the Soybean Industry (research grant number: nycytx-004), the National Research Center of Soybean Engineering and Technology and the Northeast Agricultural University for funding this work.

\section{References}

[1] E. A. Foegeding and J. P. Davis, "Food protein functionality: a comprehensive approach," Food Hydrocolloids, vol. 25, no. 8, pp. 1853-1864, 2011.

[2] Y. F. Hua, S. W. Cui, Q. Wang, Y. Mine, and V. Poysa, "Heat induced gelling properties of soy protein isolates prepared from different defatted soybean flours," Food Research International, vol. 38, no. 4, pp. 377-385, 2005.

[3] S. Utsumi and J. E. Kinsella, "Forces involved in soy protein gelation: effects of various reagents on the formation, hardness and solubility of heat-induced gels made from 7S, 11S, and soy isolate," Journal of Food Science, vol. 50, no. 5, pp. 1278-1282, 2006.

[4] N. Diftis and V. Kiosseoglou, "Stability against heat-induced aggregation of emulsions prepared with a dry-heated soy protein isolate-dextran mixture," Food Hydrocolloids, vol. 20, no. 6, pp. 787-792, 2006.

[5] G. Denavi, D. R. Tapia-Blácido, M. C. Añón, P. J. A. Sobral, A. N. Mauri, and F. C. Menegalli, "Effects of drying conditions on some physical properties of soy protein films," Journal of Food Engineering, vol. 90, no. 3, pp. 341-349, 2009.

[6] X. Li, Y. Li, Y. Hua, A. Qiu, C. Yang, and S. Cui, "Effect of concentration, ionic strength and freeze-drying on the heatinduced aggregation of soy proteins," Food Chemistry, vol. 104, no. 4, pp. 1410-1417, 2007.

[7] M. C. Puppo and M. C. Añón, "Soybean protein dispersions at acid pH. Thermal and rheological properties," Journal of Food Science, vol. 64, no. 1, pp. 50-56, 1999.

[8] J. M. S. Renkema, C. M. M. Lakemond, H. H. J. de Jongh, H. Gruppen, and T. van Vliet, "The effect of $\mathrm{pH}$ on heat denaturation and gel forming properties of soy proteins," Journal of Biotechnology, vol. 79, no. 3, pp. 223-230, 2000.

[9] M. Tezuka, K. Yagasaki, and T. Ono, "Changes in characters of soybean glycinin groups I, IIa, and IIb caused by heating," Journal of Agricultural and Food Chemistry, vol. 52, no. 6, pp. 1693-1699, 2004.
[10] S. Utsumi, S. Damodaran, and J. E. Kinsella, "Heat-induced interactions between soybean proteins: preferential association of 11S basic subunits and $\beta$ subunits of 7S," Journal of Agricultural and Food Chemistry, vol. 32, no. 6, pp. 1406-1412, 1984.

[11] C. V. Morr, "Current status of soy protein functionality in food systems," Journal of the American Oil Chemists' Society, vol. 67, no. 5, pp. 265-271, 1990.

[12] K. K. Agyare, K. Addo, and Y. L. Xiong, "Emulsifying and foaming properties of transglutaminase-treated wheat gluten hydrolysate as influenced by $\mathrm{pH}$, temperature and salt," Food Hydrocolloids, vol. 23, no. 1, pp. 72-81, 2009.

[13] J. R. Wagner, D. A. Sorgentini, and M. C. Anon, "Relation between solubility and surface hydrophobicity as an indicator of modifications during preparation processes of commercial and laboratory-prepared soy protein isolates," Journal of Agricultural and Food Chemistry, vol. 48, no. 8, pp. 3159-3165, 2000.

[14] N. S. Hettiarachchy, U. Kalapathy, and D. J. Myers, "Alkalimodified soy protein with improved adhesive and hydrophobic properties," JAOCS, Journal of the American Oil Chemists' Society, vol. 72, no. 12, pp. 1461-1464, 1995.

[15] Y. Jiang, C.-H. Tang, Q.-B. Wen, L. Li, and X.-Q. Yang, "Effect of processing parameters on the properties of transglutaminasetreated soy protein isolate films," Innovative Food Science and Emerging Technologies, vol. 8, no. 2, pp. 218-225, 2007.

[16] J.-M. Wang, N. Xia, X.-Q. Yang et al., "Adsorption and dilatational rheology of heat-treated soy protein at the oilwater interface: rlationship to structural properties," Journal of Agricultural and Food Chemistry, vol. 60, no. 12, pp. 3302-3310, 2012.

[17] M. Aider, D. Djenane, and W. B. Ounis, "Amino acid composition, foaming, emulsifying properties and surface hydrophobicity of mustard protein isolate as affected by $\mathrm{pH}$ and $\mathrm{NaCl}$," International Journal of Food Science and Technology, vol. 47, no. 5, pp. 1028-1036, 2012.

[18] H. Hu, J. H. Wu, C. Y. E. Li-Chan et al., "Effects of ultrasound on structural and physical properties of soyprotein isolate (SPI) dispersions," Food Hydrocolloids, vol. 30, pp. 647-655, 2012.

[19] L. Shen and C.-H. Tang, "Microfluidization as a potential technique to modify surface properties of soy protein isolate," Food Research International, vol. 48, no. 1, pp. 108-118, 2012.

[20] G. G. Tartaglia, A. Cavalli, R. Pellarin, and A. Caflisch, "The role of aromaticity, exposed surface, and dipole moment in determining protein aggregation rates," Protein Science, vol. 13, no. 7, pp. 1939-1941, 2004.

[21] O. H. Lowry, N. J. Rosebrough, A. L. Farr, and R. J. Randall, "Protein measurement with the Folin-Phenol reagents," The Journal of Biological Chemistry, vol. 193, pp. 265-275, 1951.

[22] A. Kato and S. Nakai, "Hydrophobicity determined by a fluorescence probe method and its correlation with surface properties of proteins," Biochimica et biophysica acta, vol. 624, no. 1, pp. 13-20, 1980.

[23] C. Y. Ma and V. R. Harwelkar, "Thermal analysis of food proteins," Journal of Food and Nutrition Research, vol. 35, pp. 317-366, 1991.

[24] E. L. Arrese, D. A. Sorgentini, J. R. Wagner, and M. C. Añón, "Electrophoretic, solubility, and functional properties of commercial soy protein isolates," Journal of Agricultural and Food Chemistry, vol. 39, no. 6, pp. 1029-1032, 1991.

[25] C. M. M. Lakemond, H. H. J. de Jongh, M. Hessing, H. Gruppen, and A. G. J. Voragen, "Heat denaturation of soy glycinin: influence of $\mathrm{pH}$ and ionic strength on molecular structure," 
Journal of Agricultural and Food Chemistry, vol. 48, no. 6, pp. 1991-1995, 2000.

[26] C. H. Tang, S. M. Choi, and C. Y. Ma, "Study of thermal properties and heat-induced denaturation and aggregation of soy proteins by modulated differential scanning calorimetry," International Journal of Biological Macromolecules, vol. 40, no. 2, pp. 96-104, 2007.

[27] A. Laligant, E. Dumay, C. C. Valencia, J.-L. Cuq, and J.C. Cheftel, "Surface hydrophobicity and aggregation of $\beta$ lactoglobulin heated near neutral pH," Journal of Agricultural and Food Chemistry, vol. 39, no. 12, pp. 2147-2155, 1991.

[28] S. Petruccelli and M. C. Añón, "Thermal aggregation of soy protein isolates," Journal of Agricultural and Food Chemistry, vol. 43, no. 12, pp. 3035-3041, 1995.

[29] D. A. Sorgentini, J. R. Wagner, and M. C. Añón, "Effects of thermal treatment of soy protein isolate on the characteristics and structure-function relationship of soluble and insoluble fractions," Journal of Agricultural and Food Chemistry, vol. 43, no. 9, pp. 2471-2479, 1995.

[30] T. Yamagishi, A. Miyakawa, N. Noda, and F. Yamauchi, "Isolation and electrophoresis analysis of heat-induced products of mixed soybean 7S and 11S globulins," Agricultural and Biological Chemistry, vol. 47, pp. 1229-1237, 1983.

[31] H.-G. Zheng, X.-Q. Yang, C.-H. Tang, L. Li, and I. Ahmad, "Preparation of soluble soybean protein aggregates (SSPA) from insoluble soybean protein concentrates (SPC) and its functional properties," Food Research International, vol. 41, no. 2, pp. 154164, 2008.

[32] A. Barth, "Infrared spectroscopy of proteins," Biochimica et Biophysica Acta-Bioenergetics, vol. 1767, no. 9, pp. 1073-1101, 2007.

[33] D. M. Byler, J. N. Brouillette, and H. Susi, "Quantitative studies of protein structure by FT-IR spectral deconvolution and curve fitting," Spectroscopy, vol. 1, pp. 29-32, 1986.

[34] A. Mauerer and G. Lee, "Changes in the amide I FT-IR bands of poly-L-lysine on spray-drying from $\alpha$-helix, $\beta$-sheet or random coil conformations," European Journal of Pharmaceutics and Biopharmaceutics, vol. 62, no. 2, pp. 131-142, 2006.

[35] E. Goormaghtigh, V. Cabiaux, and J.-M. Ruysschaert, "Secondary structure and dosage of soluble and membrane proteins by attenuated total reflection Fourier-transform infrared spectroscopy on hydrated films," European Journal of Biochemistry, vol. 193, no. 2, pp. 409-420, 1990.

[36] A. Mauerer and G. Lee, "Changes in the amide I FT-IR bands of poly-L-lysine on spray-drying from $\alpha$-helix, $\beta$-sheet or random coil conformations," European Journal of Pharmaceutics and Biopharmaceutics, vol. 62, no. 2, pp. 131-142, 2006.

[37] X. Y. Zhao, F. S. Chen, W. T. Xue, and L. T. Lee, "FTIR spectra studies on the secondary structures of $7 \mathrm{~S}$ and $11 \mathrm{~S}$ globulins from soybean proteins using AOT reverse micellar extraction," Food Hydrocolloids, vol. 22, no. 4, pp. 568-575, 2008.

[38] G. Meng and C.-Y. Ma, "Characterization of globulin from Phaseolus angularis (red bean)," International Journal of Food Science and Technology, vol. 37, no. 6, pp. 687-695, 2002.

[39] V. Rampon, P. Robert, N. Nicolas, and E. Dufour, "Protein structure and network orientation in edible films prepared by spinning process," Journal of Food Science, vol. 64, no. 2, pp. 313316, 1999.

[40] Z. Yu, C.-Y. Ma, S.-N. Yuen, and D. L. Phillips, "Raman spectroscopic determination of extent of O-esterification in acetylated soy protein isolates," Food Chemistry, vol. 87, no. 3, pp. 477-481, 2004.
[41] E. N. C. Mills, L. Huang, T. R. Noel, A. P. Gunning, and V. J. Morris, "Formation of thermally induced aggregates of the soya globulin $\beta$-conglycinin," Biochimica et Biophysica Acta-Protein Structure and Molecular Enzymology, vol. 1547, no. 2, pp. 339350, 2001.

[42] H.-J. Lee, C. Choi, and S.-J. Lee, "Membrane-bound $\alpha$-synuclein has a high aggregation propensity and the ability to seed the aggregation of the cytosolic form," Journal of Biological Chemistry, vol. 277, no. 1, pp. 671-678, 2002.

[43] T. M. Przybycien and J. E. Bailey, "Secondary structure perturbations in salt-induced protein precipitates," Biochimica et Biophysica Acta-Protein Structure and Molecular Enzymology, vol. 1076, no. 1, pp. 103-111, 1991.

[44] C. Wu, H. Lei, and Y. Duan, "Formation of partially ordered oligomers of amyloidogenic hexapeptide (NFGAIL) in aqueous solution observed in molecular dynamics simulations," Biophysical Journal, vol. 87, no. 5, pp. 3000-3009, 2004. 

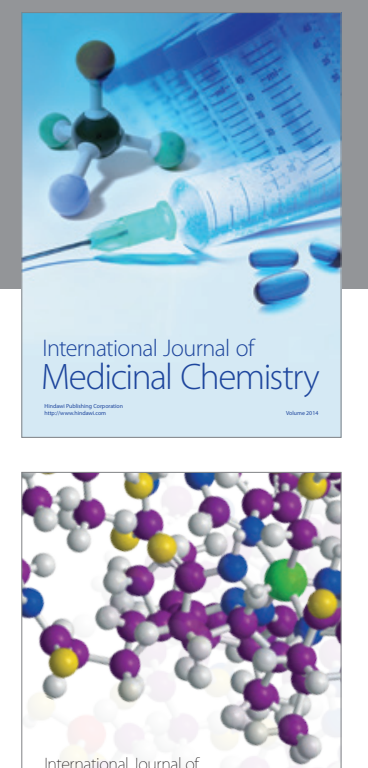

\section{Carbohydrate} Chemistry

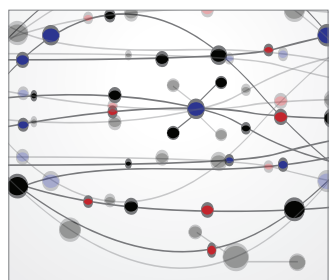

The Scientific World Journal
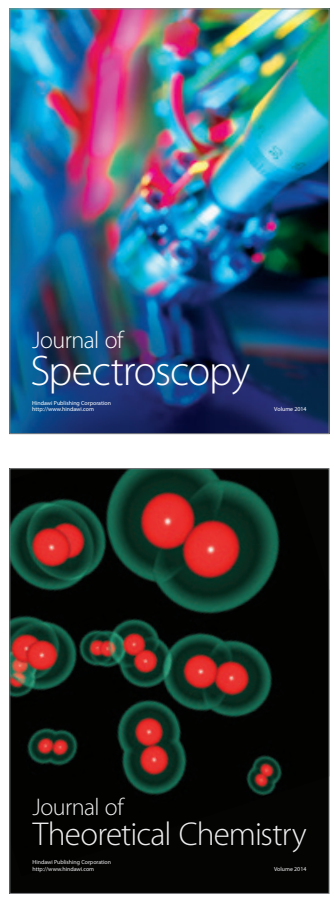
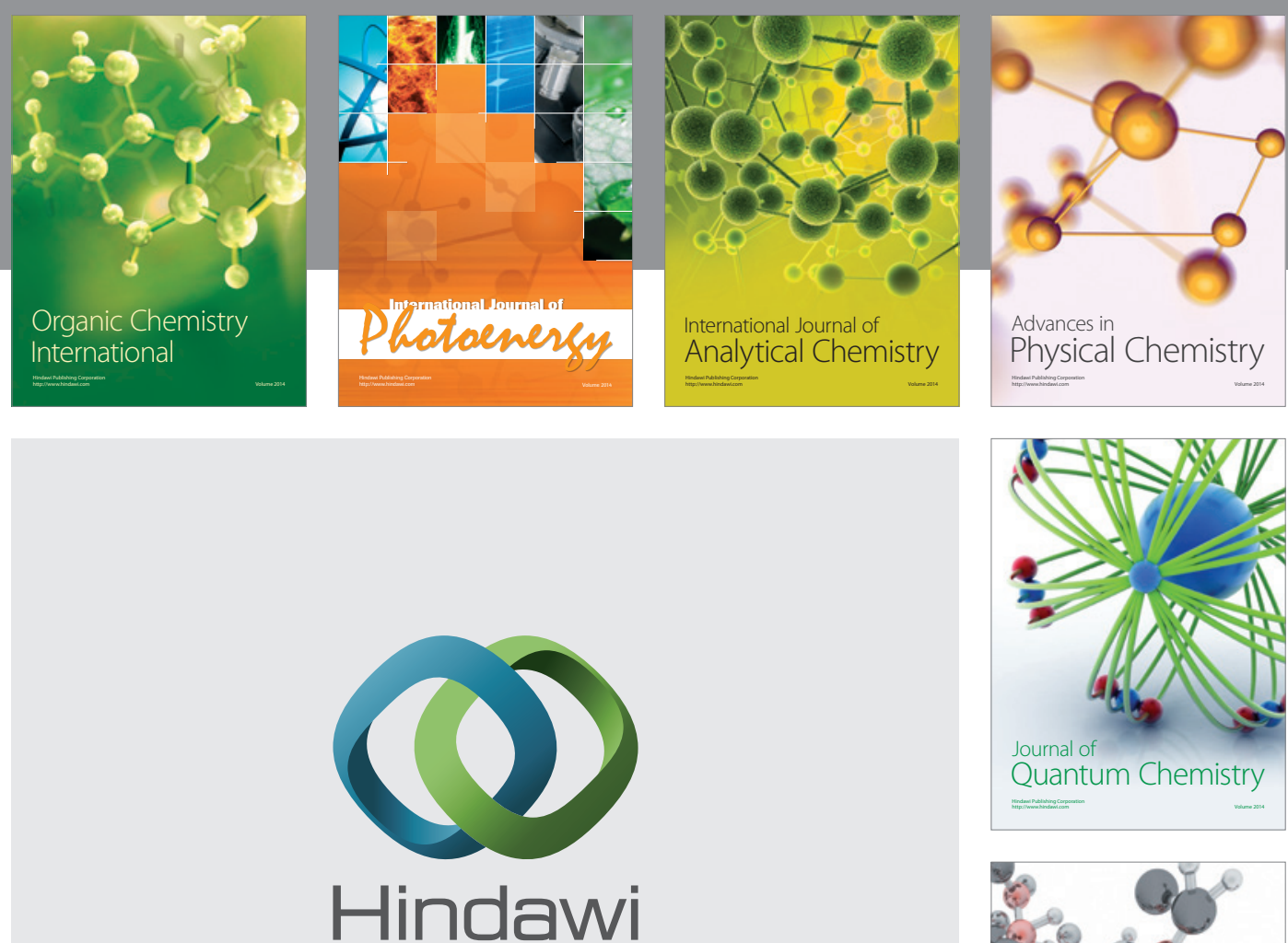

Submit your manuscripts at

http://www.hindawi.com

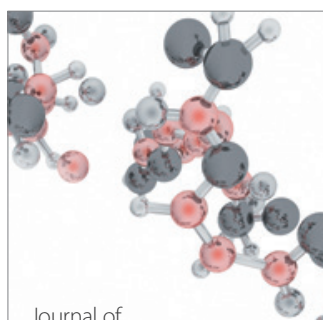

Analytical Methods

in Chemistry

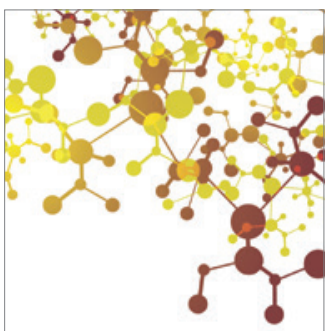

Journal of

Applied Chemistry

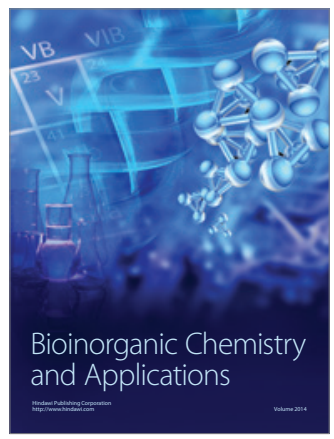

Inorganic Chemistry
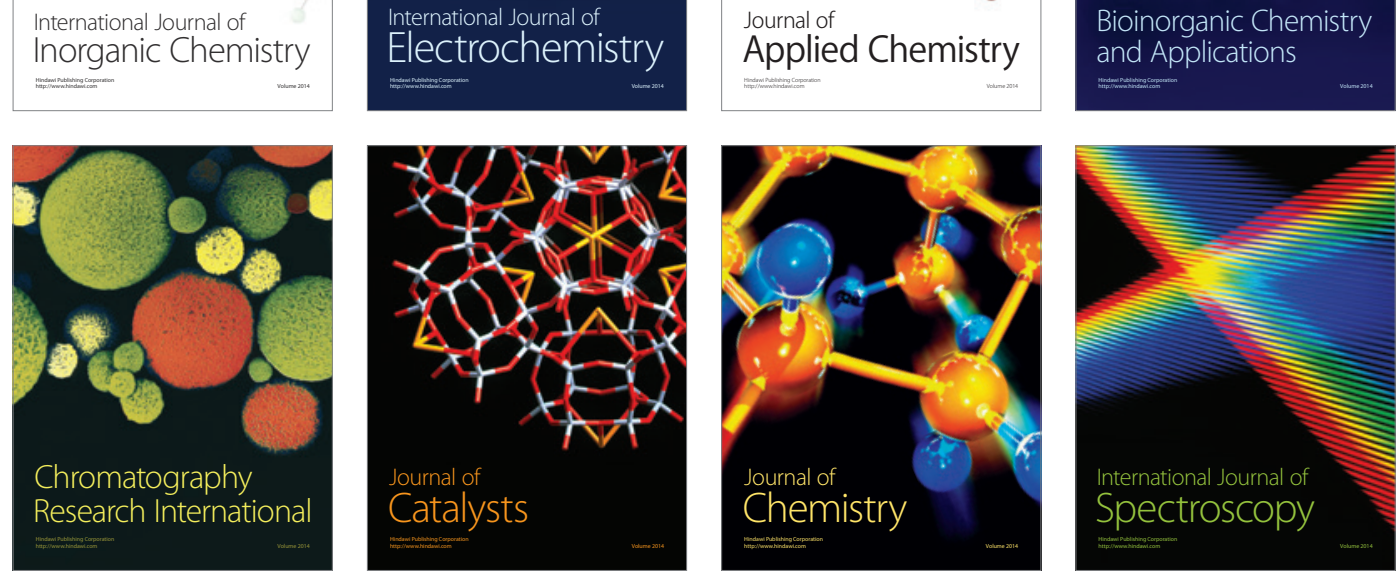